\title{
Analysis of Transcriptome Alterations in Parkinson's Disease
}

\author{
Elena Filatova, Maria Shadrina, Petr Slominsky and Svetlana Limborska \\ Institute of Molecular Genetics Russian Academy of Sciences, \\ Russian Federation
}

\section{Introduction}

The information that stems from the primary structure of DNA lies within the basis of every sign formation, although the regulation of any process occurs in different levels of cellular processes including transcription. In this context analysis of gene transcription is of great importance to improve our understanding of the pathogenesis of diverse disorders, and Parkinson's disease (PD) is not an exception. However, each disease has its own unique etiopathogenesis within organs and tissues, which is caused by disease-specific processes in cells, as well as at the genetic level. Knowledge of the etiology and pathogenesis of diseases at a cellular level opens wide prospects for diagnosis and treatment, even for complex and incurable disorders such as PD. Therefore, it is necessary to study the pathogenesis of specific disease at the cellular and genetic levels. Accordingly, the expression profiles of large numbers of genes are being studied in different neurodegenerative disorders, including PD. Although the mechanisms that initiate neuronal pathology in sporadic PD remain largely obscure, in this chapter we have tried to summarize all current knowledge in the field of the PD transcriptomics.

\section{Analysis of gene expression in PD}

\subsection{Analysis of gene expression in brain tissues}

The general approach in studying gene expression in PD is the analysis of transcript levels in tissues of the brain (the main organ that is affected in PD), which exhibit lesions that result in symptoms of PD. Unfortunately, only post-mortem tissues can be used in such studies. In addition, DNA microarrays are actively used in this type of study and there is a tendency to combine these data with the results of genome-wide association studies (GWAS) of single nucleotide polymorphisms (SNPs) and point mutations in PD (Elstner, 2009). Combined analysis allows the identification of a number of candidate genes for further study; therefore, residual genes are more likely involved in the pathogenesis of PD (Horan, 2009, Noureddine, 2005).

Thus, several tens of genes implicated in different metabolic pathways that are disturbed in PD have been identified during the analysis of transcription profiles in the substantia nigra of patients with PD. Mitochondrial dysfunction, oxidative stress, ubiquitin-proteasomal degradation of proteins, differentiation and functioning of dopaminergic (DA) neurons, DA 
metabolism, inflammation, apoptosis, and several other processes are among such metabolic pathways.

During the development of PD, there is a common tendency toward a decrease in the expression of genes that are involved in the pathogenesis of this disease (Table 1). According to some studies, the data expression of genes associated with mitochondrial functioning and oxidative stress (PARK7 and PINK) is downregulated. Although the levels of expression of genes involved in the ubiquitin-proteasomal system (UPS) were both increased and decreased in neurons of patients with PD, the downregulation of these genes is predominant especially regarding the expression of genes associated with monogenic forms of PD: SNCA, UCHL1, and ATP13A2. In addition, a lower number of transcripts were observed for lysosomal genes (mainly genes encoding proton-transporting ATP synthases) (Bossers, 2009, Duke, 2006, Elstner, 2009, Hauser, 2005, Simunovic, 2010, Simunovic, 2009).

The very interesting work of Grünblatt and co-workers (Grünblatt, 2004) showed, for the first time, the global changes in gene expression in the substantia nigra pars compacta (SNpc) of postmortem parkinsonian brains compared with aged-matched controls. It was shown that major gene downregulation was observed in the signal transduction, protein degradation, dopaminergic transmission and metabolism, ion transport, and protein modification/phosphorylation, as well as in the energy pathways/glycolysis functional classes, in PD. Regarding genes that are upregulated differentially in PD, these cluster mainly in biological processes involving cell adhesion/cytoskeleton, extracellular-matrix components, cell cycle, protein modification/phosphorylation, protein metabolism, transcription, and inflammation/stress.

Similar results were obtained later by Simunovic et al. (Simunovic, 2009), as one can see in the Table 1. Their data show a set of deregulated genes that are directly or indirectly involved in programmed cell death (PCD) confirming the current concept of the apoptotic death of the DA neuron. In addition, data show a dysfunction of both mitochondria and the UPS, which are major contributors to PCD and the pathogenesis of Parkinson's disease (Duke, 2006). It should be noted that the expression of SNCA, a component of Lewy bodies and the pathologic accumulation of which is caused by oxidative stress, mitochondrial dysfunction, and impairment of cellular proteolytic mechanisms (Lundvig, 2005, as cited in Simunovic, 2009), was also deregulated.

The expression of genes involved in the differentiation, survival, and functioning of DA neurons also changes. There is evidence of decreased expression of the NR4A2 transcription factor gene and of the $S T 13$ chaperone gene. NR4A2 encodes a transcriptional factor that is required for the differentiation of postmitotic DA neurons and for the control of the expression of genes with protein products that are associated with DA synthesis and storage, notably, the tyrosine hydroxilase gene $T H$, the dopamine-transporter gene $S L C 6 A 3$, the vesicular monoamine transporter gene VMAT2, and the amino acid decarboxylase gene AADC (Chinta \& Andersen, 2005). In turn, decreased levels of expression of the ALDH, ARPP-21 and VMAT2 genes are also possible markers of PD. The latter six genes are directly involved in the synthesis, metabolism and functioning of DA. A decrease in their expression may seriously disturb neurotransmitter storage and correlate with DA neurons dysfunction. The PDXK gene is also directly involved in the synthesis of DA. The increase of the expression of this gene in DA neurons can be explained by an adaptive mechanism of enhancement of DA metabolism in the residually functioning DA neurons of the substantia nigra, or by L-DOPA treatment (Tan, 2005). In PD, the expression of DA receptors also changes: the level of expression of D3 is reduced by $40-45 \%$ in the nucleus accumbens and in the tegmentum, and the level of D2 is increased by $15 \%$ in the tegmentum (Ryoo, 1998, Simunovic, 2010). 


\begin{tabular}{|c|c|c|}
\hline Decrease of expression & Increase of expression & Reference \\
\hline \multicolumn{3}{|c|}{ Mitochondrial functioning, oxidative phosphorylation } \\
\hline $\begin{array}{l}\text { Cytochrome c subunits } \\
\text { genes }\end{array}$ & & $\begin{array}{l}\text { (Grünblatt, 2004, Simunovic, } \\
\text { 2010, Simunovic, 2009) }\end{array}$ \\
\hline \multirow{2}{*}{$\begin{array}{l}\text { NADH dehydrogenase } \\
\text { subunits genes and } \\
\text { NADH dehydrogenase- } \\
\text { affecting proteins genes }\end{array}$} & & $\begin{array}{l}\text { (Bossers, 2009, Hauser, 2005, } \\
\text { Simunovic, 2010, Simunovic, } \\
2009 \text { ) }\end{array}$ \\
\hline & $\begin{array}{l}\text { MTND2 (subunit of } \\
\text { NADH dehydrogenase) }\end{array}$ & (Elstner, 2009) \\
\hline $\begin{array}{l}\text { proton-transporting } \\
\text { ATP-synthase complex } \\
\text { genes, }\end{array}$ & & $\begin{array}{l}\text { (Simunovic, 2010, Simunovic, } \\
\text { 2009) }\end{array}$ \\
\hline $\begin{array}{l}\text { other genes related with } \\
\text { mitochondrial } \\
\text { dysfunction }\end{array}$ & & $\begin{array}{l}\text { (Bossers, 2009, Elstner, 2009, } \\
\text { Hauser, 2005, Simunovic, 2010, } \\
\text { Simunovic, 2009) }\end{array}$ \\
\hline \multicolumn{3}{|c|}{ Oxidative stress } \\
\hline $\begin{array}{l}\text { Genes of different } \\
\text { subunits of PIK3 }\end{array}$ & $\begin{array}{l}\text { Genes of different } \\
\text { subunits of PIK3 }\end{array}$ & $\begin{array}{l}\text { (Grünblatt, 2004, Simunovic, } \\
\text { 2009) }\end{array}$ \\
\hline PINK1 и PARK7 & & $\begin{array}{l}\text { (Simunovic, 2010, Simunovic, } \\
\text { 2009) }\end{array}$ \\
\hline \multicolumn{3}{|c|}{$\begin{array}{c}\text { Ubiquitin-proteasomal system of protein degradation, proteolysis/peptidolysis, } \\
\text { lysosomes }\end{array}$} \\
\hline HIP2 & & $\begin{array}{l}\text { (Grünblatt, 2004, Moran, 2006, } \\
\text { Simunovic, 2010, Simunovic, } \\
\text { 2009) }\end{array}$ \\
\hline ATP6V1E1 & & $\begin{array}{l}\text { (Grünblatt, 2004, Simunovic, } \\
\text { 2009) }\end{array}$ \\
\hline ATP13A2, RIMS3 & RIMS1 & $\begin{array}{l}\text { (Simunovic, 2010, Simunovic, } \\
\text { 2009) }\end{array}$ \\
\hline SNCA & & $\begin{array}{l}\text { (Dachsel, 2007, Simunovic, 2010, } \\
\text { Simunovic, 2009) }\end{array}$ \\
\hline UCHL1 & & $\begin{array}{l}\text { (Hauser, 2005, Simunovic, 2010, } \\
\text { Simunovic, 2009) }\end{array}$ \\
\hline SKP1A & & (Grünblatt, 2004) \\
\hline $\begin{array}{l}\text { proton-transporting } \\
\text { ATP-synthase complex } \\
\text { genes }\end{array}$ & & $\begin{array}{l}\text { (Grünblatt, 2004, Simunovic, } \\
\text { 2010, Simunovic, 2009) }\end{array}$ \\
\hline $\begin{array}{l}\text { Other genes involved in } \\
\text { protein degradation, } \\
\text { proteasome subunits } \\
\text { genes }\end{array}$ & & $\begin{array}{l}\text { (Bossers, 2009, Grünblatt, 2004, } \\
\text { Hauser, 2005, Simunovic, 2010, } \\
\text { Simunovic, 2009) }\end{array}$ \\
\hline
\end{tabular}

Table 1. Alterations in the transcription of genes involved in different pathways in brain tissues (substantia nigra) of patients with Parkinson's disease. 


\begin{tabular}{|c|c|c|}
\hline Decrease of expression & Increase of expression & Reference \\
\hline \multicolumn{3}{|c|}{ Cytoskeleton, adhesion } \\
\hline $\begin{array}{l}\text { TUBB2 (tubulins), genes } \\
\text { coding different } \\
\text { proteins from kinesin } \\
\text { family }\end{array}$ & & $\begin{array}{l}\text { (Grünblatt, 2004, Simunovic, } \\
\text { 2009) }\end{array}$ \\
\hline $\begin{array}{l}\text { Cytoskeleton, cell } \\
\text { adhesion proteins genes }\end{array}$ & $\begin{array}{l}\text { Cytoskeleton, cell } \\
\text { adhesion proteins genes }\end{array}$ & $\begin{array}{l}\text { (Grünblatt, 2004, Simunovic, } \\
\text { 2009) }\end{array}$ \\
\hline MAPT & & (Simunovic, 2010) \\
\hline \multicolumn{3}{|c|}{ Transcription, translation, chaperones, protein modification } \\
\hline ST13 & & (Simunovic, 2010) \\
\hline NR4A2 & & (Bossers, 2009, Simunovic, 2009) \\
\hline $\begin{array}{l}\text { Other genes involved in } \\
\text { these pathways }\end{array}$ & $\begin{array}{l}\text { Other genes involved in } \\
\text { these pathways }\end{array}$ & $\begin{array}{l}\text { (Grünblatt, 2004, Noureddine, } \\
\text { 2005, Simunovic, 2009) }\end{array}$ \\
\hline \multicolumn{3}{|c|}{$\begin{array}{c}\text { Signal transduction, synaptic transmission, neurotransmitters and neurotransmitter } \\
\text { metabolism }\end{array}$} \\
\hline GABARAPL2 & $\begin{array}{l}\text { Neurotrasmitters } \\
\text { receptors genes }\end{array}$ & $\begin{array}{l}\text { (Grünblatt, 2004, Noureddine, } \\
\text { 2005, Simunovic, 2009) }\end{array}$ \\
\hline RIMS3 & & $\begin{array}{l}\text { (Moran, 2006, Simunovic, 2010, } \\
\text { Simunovic, 2009) }\end{array}$ \\
\hline ALDH1A1 & PENK & (Grünblatt, 2004) \\
\hline \multirow[t]{3}{*}{ SEC22L1, ARPP-21 } & & (Grünblatt, 2004, Zhang, 2005) \\
\hline & PDXK (DA synthesis) & (Duke, 2007, Elstner, 2009) \\
\hline & $\begin{array}{l}\text { SRGPA3 (Signal } \\
\text { transduction) }\end{array}$ & (Elstner, 2009) \\
\hline $\begin{array}{l}\text { Genes involved in } \\
\text { synaptic transmission }\end{array}$ & & $\begin{array}{l}\text { (Bossers, 2009, Noureddine, } \\
\text { 2005, Simunovic, 2009) }\end{array}$ \\
\hline Ion-channels genes & Ion-channels genes & $\begin{array}{l}\text { (Simunovic, 2010, Simunovic, } \\
\text { 2009) }\end{array}$ \\
\hline \multicolumn{3}{|c|}{ Transport } \\
\hline $\begin{array}{l}\text { solute carrier family } \\
\text { genes }\end{array}$ & solute carrier family genes & $\begin{array}{l}\text { (Grünblatt, 2004, Simunovic, } \\
\text { 2009) }\end{array}$ \\
\hline $\begin{array}{l}\text { Other transport protein } \\
\text { genes } V M A T\end{array}$ & $\begin{array}{l}\text { Other transport protein } \\
\text { genes }\end{array}$ & (Grünblatt, 2004) \\
\hline TRAPPC4 & & (Elstner, 2009) \\
\hline
\end{tabular}

Table 1. Alterations in the transcription of genes involved in different pathways in brain tissues (substantia nigra) of patients with Parkinson's disease (continuation).

The expression of genes involved in synaptic transmission and signal transduction is also altered in PD. Over the past years, there has been emerging evidence that the survival of DA neurons depends on their unique properties of electrical activity involving $\mathrm{Na}^{+}, \mathrm{K}^{+}$, and $\mathrm{Ca}^{2+}$ channels; moreover, the association between mitochondrial dysfunction and reactive oxygen species (ROS) production and $\mathrm{K}^{+}$and $\mathrm{Ca}^{2+}$ channel activation has been suspected as a major contributor to the pathogenesis Parkinson's disease (Michel, 2007 and Surmeier, 2007, as cited in Simunovic, 2009). Many molecules related to these mechanisms were shown as 
being deregulated in the data set (Simunovic, 2009). In addition, the calcium channel subunit b3 (CACNB3), the ATPase type 13A2 (PARK9), and several subunits of $\mathrm{Ca}^{2+}$ transporting ATPases (ATP2A3, ATP2B2, and ATP2C1) were downregulated in PD further substantiating the involvement of a deficit in organelle function and of $\mathrm{Ca}^{2+}$ sequestering. A decrease in the level of the transcripts of the GABA receptor genes (GABRB1, GABARAPL1/3, and GABARAPL2) has also been discovered in PD, supporting the previous suggestion that GABAergic synapses are reduced in the substantia nigra of Parkinson's disease brains, resulting in a reduction of DA neuron inhibition and an increase in neurotransmission and function of the remaining functional DA neurons (Miller \& Federoff, 2005, as cited in Simunovic, 2009). In contrast, the expression of genes encoding glutamatergic, cholinergic, somatostatinergic, and dopaminergic receptors was increased (Simunovic, 2009). The deregulation of several genes pointed to impairment of synaptic function and plasticity; some of these genes were also identified in other studies, such as SYNGR3, NSF, SV2B, SYN1, SYT1, and dynamin (Miller, 2006). The genes that were deregulated in the study of Simunovic mediate important mechanisms involved in the maintenance of synaptic function and integrity, such as those encoding a number of proteins from the SNARE complex (priming of the synaptic vesicle and synaptic vesicle surface proteins), which play a role in vesicle binding and fusion to the plasma membrane (Brunger, 2005).

However, the genes and mechanisms described above do not cover the whole spectrum of possible pathogenetic pathways underlying the sporadic form of PD. Several authors observed the upregulation of genes involved in cell adhesion and cytoskeleton (MAPT, PARVA (parvin, alpha), LGALS9, and selectin ligand $\mathrm{P}$ (SELPLG)), components of extracellular matrix (genes encoding structural proteins and phosphorylating proteins), cell cycle, inflammatory stress, and induced apoptosis (TRAF3, TNF receptor-associated factor 3 ) (Table 1). Simunovic et al. (Simunovic, 2009) detected deregulation of microtubulinassociated genes, such as MAPT, MAPRE1, TCP1 (which participate in the unfolding of translated proteins in the cytosol, such as actin and tubulin (Stirling, 2007, as cited in Simunovic, 2009)) and of multiple subunits of tubulin, but not of the microtubule-affinity regulating kinase (MARK1) and microtubule-associated protein (MAP2), as described elsewhere (Miller, 2006, Moran, 2007). Recently, the underexpression of a set of genes that are expressed in response to the PPARGC1A gene has also been shown in patients with PD in a genome-wide expression study (Zheng, 2010). Activation of PPARGC1A results in increased expression of nuclear-encoded subunits of the mitochondrial respiratory chain (Zechner, 2010). Taken together, the results of Simunovic and co-workers are consistent with other observations that point to a functional disconnect of the striatonigral trophic signaling pathways (Miller, 2006).

Currently, much data has been obtained regarding altered gene expression in brain tissues of patients with PD, especially in the substantia nigra. However, as can be seen in the studies described above, previous observations are reproduced rarely. Each study reports on different spectra of transcripts. The study of Moran et al. (Moran, 2006) is an exception, as it partly reproduced the results of Zhang et al. (Zhang, 2005), which can be explained by the fact that these authors used the same methods. Bossers et al. also replicated some of the results of Grünblatt et al. and Zhang et al. (ALDH1A1, SNCA, UCHL1, VMAT2, GBE1 and NR4A2) (Bossers, 2009). However, Moran et al. admit that they could not confirm the data of Grünblatt and Hauser, although they found similar changes in the expression of some genes ,including ALDH1A1 and NR4A2. Such difference probably can be explained by the diverse 
approaches in experimental design (different populations, different methods, and diverse comparison groups), despite the fact that all studies were performed using post-mortem samples of substantia nigra obtained from patients with PD.

Given the apparent lack of concordance among published data sets, one might wonder about the relevance of these transcriptional approaches regarding PD pathogenesis. Certainly, the use of post-mortem brain tissues appears to represent the best opportunity for finding PD-specific changes in gene expression. Furthermore, such "benchmarks" facilitate the evaluation of clinical samples and model systems for their utility in PD research. However, the approaches used to generate and analyse microarray data are not standardized; therefore, they could account for much of the apparent discrepancy observed among reported gene lists (Sutherland, 2009).

Nevertheless, despite the differences in individual gene expression data, many researchers report alterations in the expression profiles of whole groups of genes involved in specific cellular processes. Thus, a tendency toward downregulation of genes related to mitochondrial function and the ubiquitin-proteasomal system is observed, as well as the alteration of the expression of genes involved in oxidative stress, DA metabolism, transport proteins, microtubule-associated proteins of movement, and cytoskeletal proteins, thereby approving supposed picture of PD pathogenesis (Table 1). However, it is important to understand that alterations of expression likely represent late stages of PD (post mortem tissues) and cannot fully represent the entire pathogenesis of PD.

Case-control expression analysis in a degenerative disease like PD raises difficult issues when attempting to uncover pathways contributing to disease initiation. It would be advantageous to target tissues that express the proteins that are fundamental to the disease process and that are different in individuals who are at risk for the disease. At the same time, we need to account for any influences of the pathological process on these profiles. Microarray data of predilection brain sites, such as the SN, illustrate the cytoarchitectural differences between cases and controls; however, to understand some of the early pathogenic processes, ideally we would want to assay a brain region that is very similar to the SN but that is only affected belatedly.

The ability of the pathway approach that was used in the analyses of Sutherland and coworkers (Sutherland, 2009) to provide adequate specificity for PD over other neurodegenerative conditions is an additional consideration. This issue remains unclarified and requires further investigation. It is important to recognize that there may be genetic expression patterns that are common among neurodegenerative diseases in general. These may reflect common pathological changes (such as cell death, markers of oxidative stress or neuroinflammation, and etc) or shared risk factors that influence neurodegeneration. Inherent difficulties remain regarding the generation of reproducible gene expression data from post mortem brain, even if an optimal region of the brain could be assayed. Furthermore, this information can only be used retrospectively, for the potential benefit of future PD patients. Therefore, there is considerable interest in developing strategies to obtain human RNA from sources that are more accessible, such as the blood or neuronallike cell lines. However, there is a real concern that peripheral tissues, such as whole blood, may express few proteins that are fundamental for the disease process and, therefore, may have limited ability to demonstrate case-control differences that are relevant to disorders of the nervous system (Matigian, 2008). The lack of available gene expression data from multiple tissues of patients with PD at various stages of the disease precludes such an analysis, but highlights the need for ongoing research efforts in this area. At present, the 
search for expression markers of early stages of PD in tissues that are more available (e.g. blood and cerebrospinal fluid) is urgent.

\subsection{Analysis of gene expression in the peripheral blood of patients with PD}

Unfortunately, little is known currently about the expression of single genes and the expression profiles of groups of genes in the blood of patients with PD. Only a few studies report changes in the number of transcripts or protein concentration in blood cells or in plasma.

To date, there is only one report of a genome-wide expression study in the blood of patients with PD. It was shown that only 22 among 20000 genes are significantly downregulateded in PD (Scherzer, 2007). According to other data, a decreased number of transcripts has been shown for two of these genes, HIP2 and ST13, in the substantia nigra of patients with PD (Table 1). However, Scherzer et al. noticed that one of the 22 genes that was most underexpressed in PD was the heat-shock protein-70-interacting protein ST13, which belongs to the ubiquitin-proteasome pathway. ST13 is a cofactor of the heat-shock protein 70 (HSP70) and stabilizes its chaperone activity (Shi, 2007). HSP70 modulates the folding of SNCA and suppresses its toxicity in cells, yeast, and flies (Auluck, 2002, Flower, 2005, and Klucken, 2004, as cited in Scherzer, 2007). ST13 stabilizes the ADP state of HSP70, which has a high affinity for substrate proteins. Via its own chaperone activity, ST13 may contribute to the interaction of HSP70 with various target proteins (Hohfeld, 1995) that may play a role in the pathogenesis of PD. However, it is necessary to mention that we have not found any alterations in the expression of the ST13 gene in patients with PD in Russia (Shadrina, 2010). There are only a few studies on expression changes of single genes as well. Increased expression of SNCA was shown in the peripheral blood of Korean patients with a sporadic form of PD (Kim, 2004). Another study showed a direct correlation between the levels of expression of cyto/chemokines (MCP-1, RANTES, MIP-1- $\alpha$, IL-8, IFN- $\gamma$, IL-1 $\beta$, TNF- $\alpha$, and NF-kB(p65)) in peripheral white blood cells in patients with PD and stages of PD (Reale, 2009). These results reflect the deregulation of cytokines in the blood of patients with PD and possibly indicate the activation of inflammation. Recent data reported by Grünblatt et al., based on their previous study (Grünblatt, 2004), show that the expression levels of HIST1H3E, PSMA2, LAMB2, and ALDH1A1 may be biomarkers for PD diagnosis, with an achieved sensitivity and specificity of more than $80 \%$ (Grünblatt, 2010). However, the sensitivity of the clinical diagnosis of PD in symptomatic patients remains higher, as it is estimated as $91 \%$ (Hughes, 2002).

Furthermore, some studies also described alterations of protein concentrations in the blood of patients with PD. Armentero et al. showed increased levels of glycogen synthase kinase 3 (GSK-3) in peripheral lymphocytes in patients with PD (Armentero, 2010). GSK-3 has been implicated in the regulation of axonal transport (Morfini, 2002 and Pigino, 2003, as cited in Armentero, 2010) and modulates the ubiquitylation of synphilin-1, as well as its degradation, which is promoted by SIAH (Avraham, 2005, as cited in Armentero, 2010). Caronti et al. demonstrated a reduction of dopamine transporter immunoreactivity in peripheral blood lymphocytes in the early clinical stages of PD (Caronti, 2001). Despite these promising results, we have shown that the expression of GSK3B gene was not altered in the peripheral blood of Russian patients with PD (Filatova, 2011).

Nevertheless, the study of gene expression in the blood opens broad prospects for the identification of biomarkers for diagnosis of PD. Expression-profile analysis in PD will possibly allow the elucidation of the pathogenesis of the early stages of PD, which, in turn, opens wide prospects for a more adequate treatment or preventive correction of this disease. 


\subsection{Analysis of gene expression in different models of PD}

Since the discovery of PD as a single nosological form, researchers have been trying to identify the mechanisms underlying disease development and approaches to test drugs before clinical usage. However, human brain tissues are not sufficient for these purposes because of their inaccessibility during the lives of the patients. Under these circumstances, researches have had to develop various models of PD involving cell lines (including induced pluripotent stem cells) and animals (mice, rats, monkeys, and flies). Currently there is a great variety of such models, which can be divided into two large groups: genetic (endogenous) and nongenetic (exogenous). Genetic models are based on altered expression of genes involved in the pathogenesis of PD or on altered functioning of proteins encoded by these genes. Nongenetic models are based on the introduction of different inductors (e.g. neurotoxins and drugs) into model organisms or on surgery approaches that lead to parkinsonian syndrome.

Despite this variety of models of $\mathrm{PD}$ and their large impact on the elucidation of pathogenesis of this disease, the picture of the etiopathogenesis of the disorder remains approximate. Nevertheless, some reports describe changes in the whole transcriptome of model organisms.

A monkey model with MPTP-induced parkinsonism was used to show that the same pathways are altered in the substantia nigra and in the striatum, as described previously in paragraph 2.1 and in Table 1 (Ohnuki, 2010); among them are mitochondrial dysfunction, oxidative stress, signal transduction, synaptic transmission, neurotransmitters, and neurotransmitter metabolism. Genes coding for the DA phenotype, such as DAT, AADC, TH, VMAT2, and ADLH1A1, were significantly downregulated in the SN of this MPTP, which is in line with the loss of DA neuronal function that occurs in PD and MPTP model systems. Genes involved in synaptic function and cytoskeletal stability represented a major class of genes that exhibited decreased expression. It was observed that some genes were consistently downregulated across the studies of PD patients. These genes were D4S234E, NSF, CADPS, SYNJ1, AMPH, MAP1B, MAPT, dynein complex component, kinesin family members, tubulins and catenins. Interestingly, the downregulation of D4S234E, which is a neuronal endosomal gene, showed the highest concordance across PD studies. This gene is involved in the regulation of AMPA-receptor trafficking in spines and may participate in the control of synaptic strength (Alberi, 2005, as cited in Ohnuki, 2010). The downregulation of the AMPA receptor GRIA3 was also consistently observed in PD studies. These observations may provide further insight for the evaluation of the neuroprotective effects of AMPApositive allosteric modulators for the treatment of PD (O'Neill, 2005, as cited in Ohnuki, 2010). Downregulation of these synaptic transcripts in both MPTP models and PD patients suggests a significant failure in the production of the proteins necessary for vesicle trafficking and neurotransmitter release and transmission. The downregulation of several microtubule-associated proteins was also consistent in cross-comparison study (Ohnuki, 2010). The downregulation of ACTR1A, which is a component of the dynein complex, and several kinesin family member genes (KIF3A, KLC1, KIF2A, and KIFAP3) was observed in both the SN and STR (striatum). As pointed out by Miller et al. (Miller, 2006), the dynein complex and the members of the kinesin family are particularly important for bidirectional axonal transport and for the understanding of the association between the SN and the STR. Together with the downregulation of cadherins (Miller, 2006) and the overrepresentation of the cell adhesion pathway in the STR, the deregulation of the cell adhesion process seems apparent (Ohnuki, 2010). 
Multiple mechanisms have also been shown as involved in neuronal cell death in PD and model systems. Apoptotic cell death is one of the key mechanisms. Pathway enrichment of this category suggests its contribution to the cellular functions in PD and model systems. The observed upregulation of proapoptotic genes (BCL10 and TPD52L) and the downregulation of the antiapoptotic gene XIAP support the current concept of apoptosis in PD. Interestingly, XIAP is an ubiquitin-protein ligase of the UPS and has been shown to promote proteasomal degradation of caspase-3 and enhances its antiapoptotic effect (Ohnuki, 2010).

The UPS is one of the most well studied contributors to neuronal cell death in PD and model systems. The UPS is involved in the protein disposal process in cells and exerts protective effects from toxic proteins (Duke, 2006). The consistent downregulation of UCHL1 across studies implies the impairment of the ability to degrade toxic proteins. Notably, the downregulation of $\beta$-TrCP was found in the STR of the MPTP model (Ohnuki, 2010). $\beta$-TrCP is a component of the SCF ubiquitin-ligase complex, which comprises SKP1, cullin, and the F-box protein. $\beta$-TrCP functions as an F-box protein that recognizes specific targets for ubiquitination, thereby regulating the function of specific proteins, , including $\beta$-catenin and $\mathrm{NF}-\mathrm{kB}$, via protein degradation. Interestingly, SKP1, which is another component of the SCF complex, is downregulated in the SN of PD patients, as assessed using microarray data (Mandel, 2005). Furthermore, a knockdown model of SKP1 exhibited increased susceptibility to cell death (Mandel, 2009). Thus, the reduction of SCF ubiquitin-ligase activity may play an important role in neuronal cell death both in the MPTP model and in patients with PD. MPTP-induced neuronal cell death is thought to affect surrounding cells to produce signals that feed back on the remaining DA neurons (Pattarini, 2008). Genes involved in neuroinflammation likely participate in this process. In agreement with earlier studies, treatment with MPTP led to the upregulation of the astrocyte marker GFAP. Although none of the typical microglial markers, such as CD40 and CD68, was detected in the study (Ohnuki, 2010), the upregulation of complement component genes (C1S and C4B), IL-11, and proinflammatory cytokines (CXCL13 and CXCL4) suggests microglial activation (Ohnuki, 2010). These observations support the notion that microglia-derived proinflammatory factors play a role in the process of dopaminergic MPTP-induced neuronal toxicity (Whitton, 2007).

Neurotrophic support by neurotrophic and growth factors protects DA neurons (Evans \& Barker, 2008). The observed downregulation of BDNF, FGF1, FGF13, and PACAP in the STR of the MPTP model is in agreement with previous evidence. Regarding BDNF, the PD patient study found a decrease in BDNF expression in nigrostriatal DA neurons (Nagatsu, 2000). Certain transcription factors involved in survival and differentiation of DA neurons may participate in the neuroprotective function, as the loss of Nurr1 (NR4A2) (Ohnuki, 2010). Therefore, the upregulation of factors such as Nurr1 and TCF7L2 may improve the protective effects against MPTP toxicity (Bassilana, 2005). Similar to this, the upregulation of TCF7L2 was observed in the SN of the MPTP model. In contrast, Ohnuki and co-workers found robust downregulation of TCF7L2 in the STR of the MPTP model. As activation of TCF7L2 by $\beta$-catenin leads to the transcriptional initiation of the Wnt target genes (Clevers, 2006), the downregulation of TCF7L2 may influence several genes associated with survival, differentiation, and cytoskeletal stability. However, there was low consistency across the data sets of patients with PD with the exception of the occipital cortex of patients with PD (Vogt, 2006). SKP1 was also downregulated in the same region and in the BA9 region of patients with PD (Vogt, 2006, Zhang, 2005). As the pathological process of Lewy bodies 
begins in the brainstem and olfactory bulb and extends gradually to the substantia nigra and, ultimately, to the cerebral cortex (Braak, 2006), the deregulation of these genes may be associated with disease stage, in particular, with the late stage of PD.

The mitochondrial dysfunction, oxidative stress, signal transduction, synaptic transmission, neurotransmitters, and neurotransmitter metabolism pathways were also altered in the mouse models described in two other reports (Chin, 2008, Smith, 2009). Similar results were obtained in the mice and cell models described by Chung et al. and Yacoubian et al. (Chung, 2005, Yacoubian, 2008), although the two latter groups discovered changes mostly in the number of transcripts of regulatory genes.

In addition, proof of the role of mitochondrial dysfunction in PD was obtained from a genetic (SNCA A30P) fly model of the disease (Xun, 2007). This finding additionally emphasizes the role of mitochondrial dysfunction in the pathogenesis of PD.

Therefore, analysis of gene expression revealed that a number of significant pathways, including mitochondrial dysfunction, oxidative stress response, various transport pathways, signal transduction, synaptic transmission, neurotransmitters, neurotransmitter metabolism, and apoptosis, are involved in the development of PD. Nevertheless, much remains to be discovered to obtain the full picture of the pathogenesis of this disease. For example, the recently discovered microRNAs may offer new insight into the cellular mechanisms that occur during neurodegeneration.

\section{MicroRNA expression in Parkinson's disease}

Currently, research on miRNAs in the context of neurodegeneration is accumulating rapidly; the goal of this review is to provide the most complete data on the expression of microRNAs in connection with the etiopathogenesis of Parkinson's disease. Studies published recently shed some light on the role of microRNAs in the differentiation of dopaminergic neurons and raises the question of whether microRNAs are involved in the etiology of PD. There are also various reviews in this field (Barbato, 2009, Bushati \& Cohen, 2008, De Smaelea, 2010, Fiore, 2008, Hébert \& De Strooper, 2007, Lau \& de Strooper, 2010, Nelson \& Keller, 2007, Nelson, 2008, Roshan, 2009, Saugstad, 2010, Weinberg \& Wood, 2009).

Genome-encoded microRNAs (miRNAs) are known regulators of gene expression. The significance of miRNAs in various biological processes has been suggested by studies that showed an important role for these small RNAs in the regulation of cellular differentiation. However, the role of miRNAs in the regulation of the physiology of differentiated cells is not well established. Furthermore, the existence of neuron-specific miRNAs argues in favor of their important role in neuronal differentiation and/or specialized functions. The involvement of miRNAs in neuronal differentiation is strongly supported by dynamic changes in miRNA expression during brain development (Krichevsky, 2003, Miska, 2004, Smirnova, 2005). The significance of miRNAs in neuronal physiology is also suggested by data that show miRNA involvement in dendritic-spine formation and neurite outgrowth in vitro (Schratt, 2006, Vo, 2005). In summary, although there is mounting evidence of the importance of the roles of miRNAs in neuronal cell differentiation, their role in differentiated, postmitotic neurons has not been addressed fully (Schaefer, 2007).

\subsection{What is a microRNA?}

miRNAs are a class of small noncoding RNAs that induce translational repression or degradation of a target mRNA upon imperfect base pairing to its $3^{\prime}$ untranslated region 
( $\left.3^{\prime} \mathrm{UTR}\right)$. The biogenesis and mechanism of action of miRNAs are covered in detail in a number of excellent reviews (Bartel, 2004, Bartel, 2009, Bushati \& Cohen, 2007), therefore, it will be summarized briefly here. Structurally, mature miRNAs are single-stranded RNA molecules of about 21 nucleotides (nt) derived from a 70-100 nt hairpin precursor (premiRNA). miRNA genes are mostly transcribed by RNA polymerase II, with the exception of some human genes that are transcribed by RNA polymerase III (Borchert, 2006). The primary transcript, which can be up to hundreds of nt long, is then processed by the RNAse III enzyme Drosha in the nucleus, to yield a pre-miRNA. The pre-miRNA is subsequently translocated to the cytoplasm via an exportin-5-dependent mechanism. Once in the cytosol, pre-miRNAs are further processed by a second RNAse III enzyme, Dicer. Cleavage generates an imperfect, siRNA-like duplex that is unwound and whose strand with the weakest base pairing at the $5^{\prime}$ end is preferentially loaded into the RNA-induced silencing complex (RISC). Binding of the miRNA to its target occurs within the RISC and target silencing requires the presence of proteins belonging to the Argonaute (AGO) family. Complementarity between the $5^{\prime}$ end of the miRNA, the seed region, and the $3^{\prime}$ UTR of the target mRNA appears to be critical for the binding, where more variability is tolerated in the base pairing at the $3^{\prime}$ end of the miRNA (Bartel, 2004, Bushati \& Cohen, 2007). However, the range of action of miRNAs remains under active debate, as others showed that miRNAs are only active onto 3'UTR (Gu, 2009). Moreover, the mechanisms of miRNA processing at the posttranscriptional level are only beginning to be elucidated (Lau \& de Strooper, 2010).

miRNAs regulate approximately $30 \%$ of genes in the human genome (Rajewsky, 2006). The mechanism by which miRNAs silence gene expression remains an active and controversial field of investigation (Cannell, 2008, Filipowicz, 2008, Lau \& de Strooper, 2010, Vasudevan, 2007). Single miRNAs are able to target up to a few hundreds of different mRNAs (cooperativity) (Brennecke, 2005, John, 2004, Krek, 2005, Lewis, 2005). It is hardly surprising that the number of roles assigned to miRNAs during all stages of central nervous system (CNS) development and function is rapidly expanding (Fiore, 2008). One of the main mechanisms appears to be the blocking of translational initiation, but other mechanisms are likely involved (Jackson \& Standart, 2007, Pillai, 2007, Standart \& Jackson, 2007). Processing bodies (Pbodies), which are cytoplasmic foci that were originally identified as sites of mRNA storage and degradation, are critical structure for miRNA-mediated deadenylation and degradation. In addition to Pbodies, neurons contain a variety of functionally related high-molecular-weight ribonucleoprotein particles (nRNP) that are involved in the storage, dendritic trafficking, and translational control of neuronal mRNAs (Barbee, 2006, Krichevsky \& Kosik, 2001).

Elucidation of the precise biological functions of these miRNAs has been the subject of many studies. miRNAs are involved in cell differentiation, development, apoptosis, stress resistance, tumor formation, and in neurodegenerative disorders (Bushati \& Cohen, 2008, Plasterk, 2006, Santosh, 2009). Earlier studies provide some evidence of the involvement of miRNAs in Parkinson's disease (Nelson, 2008), but do not offer a full, comprehensive view of the microRNA-dependent regulation of PD genes.

It is possible that simple computational prediction of microRNA targets will shed some light on the behavior of target genes involved in Parkinson's disease. In addition, the identification of mRNA targets currently relies on prediction software (Bartel, 2009). Prediction of miRNAs using computer-based methods exhibits many advantages and aids in recognizing the molecular hallmarks of the disease that can lead to the development of effective screening tools for miRNA targets. However, the prediction of microRNA targets 
may be hindered by numerous problems, including tissue-specific expression and lack of validation. Moreover, interpretation of results is often not as evident and is further complicated by the small overlap set of predictions when comparing different algorithms. Such weakness of in silico studies can be partially compensated by predicting targets using multiple programs. The outputs can be effectively used for the development of a molecular marker for diagnosis and prognosis. Computer-based prediction of microRNA target selection undoubtedly reduces the noise, but is not sufficient to estimate the efficiency of each microRNA on the multiple targets. Therefore, computational prediction may not guide optimized selection of any single microRNA for efficient knock down and level of action; further validation of these findings using experimental approaches is required. Additional analysis and experimental validation of these results is mandatory to resolve the complexity of the selection of microRNA targets in the future (Santosh, 2009).

\subsection{MicroRNAs in Parkinson's disease}

As stated earlier, some studies provide evidences of the involvement of miRNAs in Parkinson's disease (Nelson, 2008), but they do not offer a full, comprehensive view of the microRNA-dependent regulation of PD genes. However, a causal link between a specific miRNA and a disease has been established in just a few cases, and most of the mechanistic data originate from invertebrate model systems.

An important work regarding the role of miRNAs in PD performed in Asa Abeliovich's laboratory indicates that a particular miRNA plays a significant role in the pathogenesis of this disease (Kim, 2007). Kim et al. profiled a panel of 224 miRNA precursors from the brains of Parkinson's patients and found that several miRNAs were deregulated, including the downregulation of miR-133b, which is enriched in dopaminergic neurons of the midbrain and, if overexpressed, suppresses their maturation and function. The authors showed experimentally that miR-133b is relatively highly expressed at the tissue level in the midbrain under normal conditions, but not in PD. Furthermore, the general knockout of miRNAs in vivo, or of miR-133b by itself in cultures of dopaminergic neurons, cultures derived from ES cells, or midbrain cultures, dramatically decreases the levels of tyrosine hydroxylase and dopamine transporter in dopaminergic neurons. Mir-133 appears to act as a negative regulator of dopaminergic neuron maturation, as overexpression and inhibition of miR-133b resulted in the decrease and increase, respectively, of the number of DA neurons in these cultures. The data also support the hypothesis that miR-133b and the paired-like homeodomain transcription factor PITX3 regulate each other's expression. In homology with miR-124, miR-133b seems to be a component of a negative feedback loop. In this case, miR-133b targets the transcription factor and marker for DA neurons, PITX3, which in turn is a positive regulator of miR-133b. Thus, loss of Pitx3 leads to the loss of miR$133 \mathrm{~b}$ in the PD model. Interestingly, aphakia mice are deficient in Pitx3, which is a homeobox transcription factor required for the survival of DA neurons and for motor activity (van den Munckhof, 2003, as cited in Fuchs, 2007). Polymorphisms in PITX3 have also been associated with PD in humans (Bergman, 2008, Fuchs, 2007).

This study is important for a number of reasons. First, it indicates a discrete role for a particular miRNA in dopaminergic function. Second, no particular miRNA-mRNA pair had been strongly implicated previously in a prevalent neurodegenerative disease. In other words, these investigators provided plausible molecular neurobiological breakthroughs for both miRNA function and dysfunction. This study also demonstrates how miRNAs can be an important component of a "downward spiral" during neurodegeneration (Nelson, 2008). 
Whether the loss of the miRNA contributes to the etiology of PD is an important, albeit unanswered, question. This has not been addressed directly in the mouse model because mutants lacking miR-133b are not available.

The relationship between miR-133b and the maturation of DA neurons is especially intriguing, for two reasons. Firstly, mice with a conditional deletion of Dicer in DA neurons display progressive loss of DA neurons (Kim, 2007). Importantly, this phenotype is also observed in vitro in a dopaminergic stem cell differentiation paradigm, and can be partially rescued by transfection of the cultures with a small RNA population isolated from wild type cells. Secondly, and puzzlingly, miR-133b is undetectable in the midbrain of patients with Parkinson's disease (Kim, 2007). This apparent contradiction awaits further validation; however, it strongly suggests additional functions of miR-133 in DA neurons.

Interestingly, neurodegeneration is also observed in mice that lack Dicer specifically in the cerebellum. In these animals, Purkinje neurons progressively degenerate and the animals develop ataxia (Schaefer, 2007). Authors demonstrated an essential role for Dicer and miRNAs in the regulation of postmitotic neuronal survival. Although Dicer deficiency had no immediate impact on Purkinje cell function, the long-term absence of Dicer resulted in a neurodegenerative process. This pattern of Purkinje cell degeneration in the absence of miRNAs bears obvious similarities to processes associated with the slow, progressive neurodegenerative diseases, such as Alzheimer's and Parkinson's diseases. Deletion of Dicer impairs the ability of embryonic stem cells to differentiate into DA neurons, by blocking miRNA biogenesis. As Dicer deletion was partially rescued by transfection of a small RNA derived from embryonic mouse midbrain, it is likely that microRNAs are involved in the differentiation and survival of DA neurons (Kim, 2007). In addition, specific deletion of Dicer in vivo, in mouse midbrain dopaminergic neurons, leads to cell death in the substantia nigra. Behavioral studies of these animals revealed reduced locomotion in an open-field assay, which was reminiscent of the phenotype of human patients with PD. Thus, although miR-133b is involved in the differentiation and function of DA neurons, additional microRNAs should be responsible for the Dicer deletion phenotype in DA neurons (Sethupathy \& Collins, 2008).

Together, these observations raise the possibility that the loss of miRNAs is involved in the emergence and/or progression of PD. Although its expression is lost in PD samples, these findings indicate that miR-133b cannot be the miRNA species that is responsible for the embryonic stem cell Dicer phenotype or the progressive loss of mouse midbrain DA neurons in Dicer mutants. PD probably results from the loss of PITX3-dependent expression of genes other than miR-133b. The miRNA(s) carrying a protective potential against DA neuron neurodegeneration remain unidentified. This profound loss of DA neurons in the substantia nigra contrasts with results of a study in which Dicer was removed from the dopaminoceptive neurons of the striatum (Cuellar, 2008). A range of phenotypes was observed, including reduction of the size of the brain and of neurons, ataxia, wasting, and premature death; however, the dopaminoceptive neurons survived throughout the lives of the animals. Therefore, in general, Dicer does not seem to be required for the promotion of cell survival in all postmitotic neurons, as Dicer is also dispensable in mature olfactory neurons (Choi, 2008). Notably, dysfunction, but not necessarily extensive loss, of dopaminoceptive neurons has also been implicated in PD (Evans \& Lees, 2004).

Another miRNA has also been associated with the development of PD. A linkage analysis in PD reported in 2001 for identified a linkage peak on chromosome 8 that harbored the fibroblast growth factor 20 (FGF20) gene (Scott, 2001), which is preferentially expressed in 
the substantia nigra and promotes the survival of dopaminergic neurons. A subsequent Comparative Genomic Analysis Study (CGAS) reported in 2004 identified rs1989754 within FGF20 as associated with PD (van der Walt, 2004). Therefore, Wang et al. (Wang, 2008) selected FGF20 for further association testing using a family-based design. The authors observed that the strongest association $(P=0.0001)$ occured with rs12720208 [C/T], a SNP that was demonstrated as mediating the allele-specific in vitro targeting of miR-433 to the 3'UTR of FGF20. The authors also showed that miR-433 is highly expressed in the brain. Unlike prior studies, these researches went even further by providing human in vivo validation and testing a molecular mechanism by which differential miR-433 targeting potentially leads to PD. In cell culture experiments and in PD brains, increased translation of FGF20 was correlated with increased expression of a-synuclein.

Two independent GWASs for PD did not test rs12720208 (Fung, 2006, Maraganore, 2005). However, one of these studies tested a nearby SNP (rs1989754) and found no signal for association $(\mathrm{P}=0.40)$ (Fung, 2006). The other study also tested another SNP within FGF20 (rs17515020) and observed a modest signal for association with PD (P = 0.03) (Maraganore, 2005). However, this result was not significant after correction for multiple testing (Maraganore, 2005). According to the phased HapMap CEU genotype data, rs12720208 is not in strong LD with either rs1989754 $(\mathrm{r} 2=0.1)$ or $\mathrm{rs} 17515020\left(\mathrm{r}^{2}=0.029\right)$; therefore, this SNP may still be associated with PD independently. Given that this study was not confounded by population stratification because of the use of a family-based association study design, and given that there is compelling functional evidence for both allele-specific targeting and an underlying molecular mechanism for the role of miR-433-FGF20 in PD pathogenesis, rs12720208 is the most attractive human poly-miRTS for use in future replication studies (Sethupathy \& Collins, 2008). However, there was no association between the FGF20 SNP rs12720208 and Parkinson's disease in Spanish patients (de Mena, 2010).

Overexpression of SNCA appears to be a common feature in PD and other asynucleinopathies. In addition, it was demonstrated recently that miR-7 interacts in vitro with the $3^{\prime} U T R$ of SNCA, represses the expression a-synuclein and inhibits a-synucleinmediated cell death (Junn, 2009). Of note, miR-7 inhibits the cellular susceptibility of neuroblastoma cells to oxidative stress induced by a mutant form of SNCA, providing evidence that miRNAs protect neuronal cells against cellular stress. The presence of miR-7 in the substantia nigra was also validated, thus supporting a physiological role for this molecule in DA neurons. However, miR-7 was initially reported as highly expressed in the mouse pituitary gland (Bak, 2008, as cited in Lau \& de Strooper, 2010) and its expression was $\sim 15$-fold lower in the substantia nigra compared with the pituitary gland, leaving open the possibility that other miRNAs regulate dopaminergic neurons in amore dynamic and efficient manner (Lau \& de Strooper, 2010).

One of the latest studies on this subject revealed a previously unknown mechanism of regulation of SNCA levels in the nervous system (Doxakis, 2010). Specifically, two brainenriched miRNAs, miR-7 and miR-153, were shown to bind directly to the 3'UTR of the SNCA mRNA and reduce its levels significantly. RNA and protein expression analysis showed developmental and tissue coexpression among miR-7, miR-153, and SNCA. The results of the study indicate that miR-7 and miR-153 have synergistic effect, require the 3'UTR of SNCA mRNA to regulate SNCA protein expression, do not interact with the coding region of SNCA to regulate the expression of SNCA protein, and act at the pretranslational level. Taking into consideration the two types of miRNA function, these findings strongly suggest that miR-7 and miR-153 play a role in the modulation/buffering of SNCA protein levels in the nervous system. 
As neither of the miRNAs is fully complementary to the SNCA mRNA - to allow endonucleolytic cleavage by Argonaute proteins - the degradation effect is likely to stem from the accelerated level of deadenylation and decapping of the SNCA mRNA, induced by the binding of miR-7 and miR-153 to its 3'UTR (Behm-Ansmant, 2006 and Eulalio, 2009, as cited in Doxakis, 2010). miR-7, miR-153, and the SNCA mRNA and protein show highest expression in neural tissues, such as the midbrain, hippocampus, and cortex (the levels of miR-7, miR-153, and SNCA mRNA are significantly higher in neurons compared with astrocytes), and lowest expression in nonneural tissues, such as the lung and heart. Interestingly, all three RNA species show highest expression in the midbrain, indicating that deregulation of their expression levels may be important in the pathogenesis of PD. The SNCA protein is also detected in the lung, as a result of the high amount of peripheral blood present in this tissue. Moreover, the expression profiles of the SNCA mRNA and protein are similar, indicating that, during development, a constant level of the miRNA-regulated SNCA mRNA is translated into protein. These results suggest that miR-7 and miR-153 are coexpressed with SNCA in neurons to regulate its levels via a transcriptional feed-forward loop that fine-tunes, rather than blocks, the expression and translation of the SNCA mRNA (Doxakis, 2010).

\section{Conclusions}

Most neurochemical and gene expression studies on the mechanism of DA neuron death in PD and its animal models, have been conducted at a time when the majority of dopamine neurons are dead. However, the detailed profile of the crucial initial neurochemical and gene expression changes in injured (but not dead) neurons is more important, as the early genetic and biochemical alterations differ from those that occur at the time of neuronal death.

It is also important to emphasize that mRNA data reveal information on the transcriptional activation of genes, but do not provide much information on the actual protein levels and function. In addition, array data cannot predict whether deregulated gene expression is a primary or a secondary effect of cell function. For example, a gene could be down- or upregulated by factors such as miRNAs or transcriptional activators (or inhibitors), independent of its protein function and/or as a consequence of positive and negative feedback loops. Moreover, protein function relies on the interaction of down- and upstream factors within a pathway, i.e. downstream factors are more dependent on upstream signaling compared with upstream factors, which may influence a cascade of downstream events that can include multiple pathways. Thus, the consequences of deregulated gene expression are exerted on multiple levels within a complex and dynamic interplay of factors and mechanisms. Laser-microscopy-based microarray studies can only provide a "snapshot" of these events. Nevertheless, several studies showed that many genes associated with the pathogenesis of Parkinson's disease are deregulated in single captured postmortem DA neurons. This could provide a "molecular fingerprint identity" of a latestage DA neuron affected by sporadic Parkinson's disease. The striking downregulation of PARK genes is a key aspect. As their mutation-induced malfunction in the familial forms of Parkinson's disease rapidly accelerates DA neuron degeneration, the results from the studies reviewed may support the view that these genes are also involved in the pathogenesis of sporadic Parkinson's disease. Data also point to an imbalance in neuronal homeostasis and stress characterized by factors related to high metabolic rate, 
neurotransmission and ion-channel activity. This stress may be part of the normal homeostasis and aging of DA neurons, but could be exacerbated in the presence of an unfavorable imbalance. In addition, the array data suggest a disintegration of key cellular functions, such as mitochondria-associated energy metabolism, protein degradation, synaptic function, and cytoskeletal integrity, revealing a cellular state that is characterized by programmed cell death. However, despite this cellular demise, some genes linked to survival mechanisms were upregulated, indicating the activation of compensatory mechanisms. Finally, the lack or the relatively modest deregulation of genes important for the DA neuronal phenotype suggests that the DA neurotransmitter identity (including DA production) seems to be sustained even when the neurons are severely damaged. It appears that the gene expression profile of the DA neurons of late-stage Parkinson's disease is consistent with the view that Parkinson's disease is a complex disorder and that multiple factors and cellular pathways are involved in its pathogenesis.

To date, whether miRNAs are also actively involved in the etiology or progression of neurodegenerative disorders remains uncertain. These small regulators clearly seem to be required for the survival of specific types of mature neurons in some model organisms; however, whether the loss of individual miRNAs can account for the drastic disease phenotypes remains to be determined. As many different cellular processes have been implicated in neurodegenerative disorders, the miRNAs involved in these pathways will obviously be found as misregulated in disease tissues. However, the degree to which their misregulation is causative in the diseases remains a pressing, but unanswered, question. Identification of causal links opens prospects for therapeutic intervention, perhaps by replacing missing miRNAs or blocking the activity of miRNAs that are overexpressed. Similarly, some miRNAs seem to have a neuroprotective role; therefore, they could potentially be used to prevent, or at least decelerate, the progressive loss of neurons in the diseased brain. These are tantalizing prospects that remain far from our grasp (Bushati \& Cohen, 2008). Studies of miRNA in neurodegenerative diseases are emerging. Currently, both changes in the expression profiles of several miRNA and polymorphisms affecting the interactions between miRNAs and their targets are being addressed in various studies on neurodegenerative disease. It is difficult to determine if the changes in miRNA expression detected in the brains or cerebrospinal fluid (CSF) of patients are primary or secondary events, or both. Nevertheless early or late in the evolution of the disease, they may contribute to the pathogenesis of the observed lesions and neuronal loss. Unique patterns of miRNA expression in the CSF of particular neurodegenerative diseases may be useful as molecular biomarkers for disease diagnosis and, eventually, for the prediction of therapeutic responses. The identification of miRNAs that cause a specific pathology could open new therapeutic perspectives to block endogenous miRNAs or deliver exogenous miRNAs. To date either antisense oligonucleotides that are chemically modified (Meister, 2004) or expressed sequences corresponding to multiple miRNA seed targets (miRNA sponge) (Ebert, 2007) have been used as microRNA inhibitors. Delivery of these molecules to the central nervous system, while avoiding toxicities, may be the challenge of future research in this area. Furthermore, as specific nuclear or cytoplasmic protein accumulation causes the neuropathological manifestation in several neurodegenerative disorders, the identification of microRNAs that regulate the translation of these targets may represent the first step toward therapeutic applications. The second step might be the evaluation of the quantitative effects of specific amounts of "therapeutic" microRNAs on the proteome (Barbato, 2009). 


\section{Acknowledgements}

This work has been supported in part by grants of the Russian Basic Research Foundation (Grants 07-04-01511, 07-04-00027, 09-04-01237-a), State Contracts (02.740.11.0084, P419, P1055), Russian Academy of Sciences program "Molecular and Cellular Biology" Russian Academy of Sciences program "Basic Sciences for Medicine".

\section{References}

Armentero, M.T., Sinforiani, E., Ghezzi, C., Bazzini, E., Levandis, G., Ambrosi, G., Zangaglia, R., Pacchetti, C., Cereda, C., Covab, E., Basso, E., Celi, D., Martignoni, E., Nappi, G. \& Blandini, F. (2010). Peripheral expression of key regulatory kinases in Alzheimer's disease and Parkinson's disease. Neurobiology of Aging, (January 2010), pp. ISSN 0197-4580

Barbato, C., Ruberti, F. \& Cogoni, C. (2009). Searching for MIND: MicroRNAs in Neurodegenerative Diseases. Journal of Biomedicine and Biotechnology, Vol.2009, (August 2009), pp. 871313, ISSN 1110-7251

Barbee, S.A., Estes, P.S., Cziko, A.M., Hillebrand, J., Luedeman, R.A., Coller, J.M., Johnson, N., Howlett, I.C., Geng, C., Ueda, R., Brand, A.H., Newbury, S.F., Wilhelm, J.E., Levine, R.B., Nakamura, A., Parker, R. \& Ramaswami, M. (2006). Staufen- and FMRP-containing neuronalRNPs are structurally and functionally related to somatic P bodies. Neuron, Vol.52, No.6, (December 2006), pp. 997-1009, ISSN 10974199

Bartel, D.P. (2004). MicroRNAs: Genomics, Biogenesis, Mechanism, and Function. Cell, Vol.116, (January 2004), pp. 281-297, ISSN 0092-8674

Bartel, D.P. (2009). MicroRNAs: target recognition and regulatory functions. Cell, Vol.136, No.2, (January 2009), pp. 215-233, ISSN 0092-8674

Bassilana, F., Mace, N., Li, Q., Stutzmann, J.M., Gross, C.E., Pradier, L., Benavides, J., Ménager, J. \& Bezard, E. (2005). Unraveling substantia nigra sequential gene expression in a progressive MPTP-lesioned macaque model of Parkinson's disease. Neurobiol Dis, Vol.20, No.1, (October 2005), pp. 93-103, ISSN 0969-9961

Bergman, O., Hakansson, A., Westberg, L., Nordenström, K., Carmine Belin, A., Sydow, O., Olson, L., Holmberg, B., Eriksson, E. \& Nissbrandt, H. (2008). PITX3 polymorphism is associated with early onset Parkinson's disease. Neurobiol Aging, Vol.31, No.1, (January 2010), pp. 554-565, ISSN 0197-4580

Borchert, G.M., Lanier, W. \& Davidson, B.L. (2006). RNA polymerase III transcribes human microRNAs. Nat Struct Mol Biol, Vol.13, No.12, (December 2006), pp. 1097-1101, ISSN 1545-9985

Bossers, K., Meerhoff, G., Balesar, R., van Dongen, J.W., Kruse, C.G., Swaab, D.F. \& Verhaagen, J. (2009). Analysis of Gene Expression in Parkinson's Disease: Possible Involvement of Neurotrophic Support and Axon Guidance in Dopaminergic Cell Death. Brain Pathology, Vol.19, No.1, (January 2009), pp. 91-107, ISSN 1015-6305

Braak, H., Müller, C.M., Rüb, U., Ackermann, H., Bratzke, H., de Vos, R.A. \& Del Tredici, K. (2006). Pathology associated with sporadic Parkinson's disease--where does it end? J Neural Transm Suppl, Vol.2006, No.70, (2006), pp. 89-97, ISSN 0303-6995

Brennecke, J., Stark, A., Russell, R.B. \& Cohen, S.M. (2005). Principles of MicroRNA-Target Recognition. PLoS Biology, Vol.3, No.3, (March 2005), pp. e85, ISSN 1545-7885

Brunger, A.T. (2005). Structure and function of SNARE and SNARE-interacting proteins. $Q$ Rev Biophys, Vol.38, No.1, (February 2005), pp. 1-47, ISSN 1469-8994 
Bushati, N. \& Cohen, S.M. (2007). microRNA Functions. Annu Rev Cell Dev Biol, Vol.23, (May 2007), pp. 175-205, ISSN 1530-8995

Bushati, N. \& Cohen, S.M. (2008). microRNAs in neurodegeneration. Current Opinion in Neurobiology, Vol.18, (June 2008), pp. 292-296, ISSN 1873-6882

Cannell, I.G., Kong, Y.W. \& Bushell, M. (2008). How do microRNAs regulate gene expression? Biochemical Society Transactions, Vol.36, No.6, (December 2008), pp. 1224-1231, ISSN 1470-8752

Caronti, B., Antonini, G., Calderaro, C., Ruggieri, S., Palladini, G., Pontieri, F.E. \& Colosimo, C. (2001). Dopamine transporter immunoreactivity in peripheral blood lymphocytes in Parkinson's disease. J Neural Transm, Vol.108, No.7, (July 2001), pp. 803-807, ISSN 1435-1463

Chin, M.H., Qian, W.-J., Wang, H., Petyuk, V.A., Bloom, J.S., Sforza, D.M., Lac'an, G., Liu, D., Khan, A.H., Cantor, R.M., Bigelow, D.J., Melega, W.P., Camp, D.G., Smith, R.D. \& Smith, D.J. (2008). Mitochondrial Dysfunction, Oxidative Stress, and Apoptosis Revealed by Proteomic and Transcriptomic Analyses of the Striata in Two Mouse Models of Parkinson's Disease. Journal of Proteome Research, Vol.7, No.2, (January 2008), pp. 666-677, ISSN 1535-3907

Chinta, S.I. \& Andersen, J.K. (2005). Dopaminergic neurons. Intern J Biochem Cell Biol, Vol.37, No.5, (May 2005), pp. 942-946, ISSN 1357-2725

Choi, P.S., Zakhary, L., Choi, W.Y., Caron, S., Alvarez-Saavedra, E., Miska, E.A., McManus, M., Harfe, B., Giraldez, A.J., Horvitz, R.H. \& et al. (2008). Members of the miRNA200 family regulate olfactory neurogenesis. Neuron, Vol.57, (January 2008), pp. 4155, ISSN 1097-4199

Chung, C.Y., Seo, H., Sonntag, K.C., Brooks, A., Lin, L. \& Isacson, O. (2005). Cell typespecific gene expression of midbrain dopaminergic neurons reveals molecules involved in their vulnerability and protection. Hum Mol Genet, Vol.14, No.13, (July 2005), pp. 1709-1725, ISSN 1460-2083

Clevers, H. (2006). Wnt/beta-catenin signaling in development and disease. Cell, Vol.127, No.3, (November 2006), pp. 469-480, ISSN 0092-8674

Cuellar, T.L., Davis, T.H., Nelson, P.T., Loeb, G.B., Harfe, B.D., Ullian, E. \& McManus, M.T. (2008). Dicer loss in striatal neurons produces behavioral and neuroanatomical phenotypes in the absence of neurodegeneration. Proc Natl Acad Sci U S A, Vol.105, (April 2008), pp. 5614-5619, ISSN 1091-6490

Dachsel, J.C., Lincoln, S.J., Gonzalez, J., Ross, O.A., Dickson, D.W. \& Farrer, M.J. (2007). The Ups and Downs of alpha-Synuclein mRNA Expression. Movement Disorders, Vol.22, No.2, (November 2006), pp. 293-295, ISSN 1531-8257

de Mena, L., Cardo, L.F., Coto, E., Miar, A., Díaz, M., Corao, A.I., Alonso, B., Ribacoba, R., Salvador, C., Menéndez, M., Morís, G. \& Alvarez, V. (2010). FGF20 rs12720208 SNP and microRNA-433 variation: No association with Parkinson's disease in Spanish patients. Neuroscience Letters, Vol.479 (July 2010), pp. 22-25, ISSN 0304-3940

De Smaelea, E., Ferrettia, E. \& Gulino, A. (2010). MicroRNAs as biomarkers for CNS cancer and other disorders. Brain Research, Vol.1338, (April 2010), pp. 100 - 111, ISSN 18726240

Doxakis, E. (2010). Post-transcriptional Regulation of a-Synuclein Expression by mir-7 and mir-153. The Journal of Biological Chemistry, Vol.285, (April 2010), pp. 12726-12734, ISSN 1083-351X

Duke, D.C., Moran, L.B., Pearce, R.K.B. \& Graeber, M.B. (2007). The medial and lateral substantia nigra in Parkinson's disease: mRNA profiles associated with higher 
brain tissue vulnerability. Neurogenetics Vol.8, (January 2007), pp. 83-94, ISSN 13646753

Duke, D.C., Moran, L.B., Kalaitzakis, M.E., Deprez, M., Dexter, D.T., Pearce, R.K. \& Graeber, M.B. (2006). Transcriptome analysis reveals link between proteasomal and mitochondrial pathways in Parkinson's disease. Neurogenetics, Vol.7, No.3, (July 2006), pp. 139-148, ISSN 1364-6753

Ebert, M.S., Neilson, J.R. \& Sharp, P.A. (2007). MicroRNA sponges: competitive inhibitors of small RNAs in mammalian cells. Nature Methods, Vol.4, No.9, (August 2007), pp. 721 - 726, ISSN 1548-7105

Elstner, M., Morris, C.M., Heim, K., Lichtner, P., Bender, A., Mehta, D., Schulte, C., Sharma, M., Hudson, G., Goldwurm, S., Giovanetti, A., Zeviani, M., Burn, D.J., McKeith, I.G., Perry, R.H., Jaros, E., Kruger, R., Wichmann, H.-E., Schreiber, S., Campbell, H., Wilson, J.F., Wright, A.F., Dunlop, M., Pistis, G., Toniolo, D., Chinnery, P.F., Gasser, T., Klopstock, T., Meitinger, T., Prokisch, H. \& Turnbull, D.M. (2009). Single-Cell Expression Profiling of Dopaminergic Neurons Combined with Association Analysis Identifies Pyridoxal Kinase as Parkinson's Disease Gene. Ann Neurol, Vol.66, (December 2009), pp. 792-798, ISSN 1531-8249

Evans, A.H. \& Lees, A.J. (2004). Dopamine dysregulation syndrome in Parkinson's disease. Curr Opin Neurol, Vol.17, (August 2004), pp. 393-398, ISSN 1473-6551

Evans, J.R. \& Barker, R.A. (2008). Neurotrophic factors as a therapeutic target for Parkinson's disease. Expert Opin Ther Targets, Vol.12, No.4, (April 2008), pp. 437-447, ISSN 17447631

Filatova, E.V., Shadrina, M.I., Karabanov, A.V., Slominsky, P.A., Illarioshkin, S.N., IvanovaSmolenskaya, I.A. \& Limborska, S.A. (2011). Expression of GSK3B gene in peripheral blood in patient with Parkinson's Disease. Molekuliarnaia biologiia, Vol.45, No.2, (March 2011), pp. 1-5, ISSN 0026-8984

Filipowicz, W., Bhattacharyya, S.N. \& Sonenberg, N. (2008). Mechanisms of posttranscriptional regulation by microRNAs: are the answers in sight? Nature Reviews. Genetics, Vol.9, (February 2008), pp. 102-114, ISSN 1471-0064

Fiore, R., Siegel, G. \& Schratt, G. (2008). MicroRNA function in neuronal development, plasticity and disease. Biochimica et Biophysica Acta, Vol.1779 No.8, (August 2008), pp. 471-478, ISSN 0006-3002

Fuchs, J., Mueller, J.C., Lichtner, P., Schulte, C., Munz, M., Berg, D., Wullner, U., Illig, T., Sharma, M. \& Gasser, T. (2007). The transcription factor PITX3 is associated with sporadic Parkinson's disease. Neurobiology of Aging, Vol.30, No.5, (May 2009), pp. 731-738, ISSN 0197-4580

Fung, H.-C., Scholz, S., Matarin, M., Simón-Sánchez, J., Hernandez, D., Britton, A., Gibbs, J.R., Langefeld, C., Stiegert, M.L., Schymick, J., Okun, M.S., Mandel, R.J., Fernandez, H.H., Foote, K.D., Rodríguez, R.L., Peckham, E., De Vrieze, F.W., Gwinn-Hardy, K., Hardy, J.A. \& Singleton, A. (2006). Genome-wide genotyping in Parkinson's disease and neurologically normal controls: first stage analysis and public release of data. Lancet Neurol, Vol.5, (November 2006), pp. 911-916, ISSN 1474-4465

Grünblatt, E., Zehetmayer, S., Jacob, C.P., Müller, T., Jost, W.H. \& Riederer, P. (2010). Pilot study: peripheral biomarkers for diagnosing sporadic Parkinson's disease. J Neural Transm, Vol.117, No.12, (December 2010), pp. 1387-1393, ISSN 1435-1463

Grünblatt, E., Mandel, S., Jacob-Hirsch, J., Zeligson, S., Amariglo, N., Rechavi, G., Li, J., Ravid, R., Roggendorf, W., Riederer, P. \& Youdim, M.B.H. (2004). Gene expression profiling of parkinsonian substantia nigra pars compacta; alterations in ubiquitinproteasome, heat shock protein, iron and oxidative stress regulated proteins, cell 
adhesion/cellular matrix and vesicle trafficking genes. J Neural Transm, Vol.111, (September 2004), pp. 1543-1573, ISSN 1435-1463

Gu, S., Jin, L., Zhang, F., Sarnow, P. \& Kay, M.A. (2009). Biological basis for restriction of microRNA targets to the $3^{\prime}$ untranslated region in mammalian mRNAs. Nature Structural \& Molecular Biology, Vol.16, No.2, (February 2009), pp. 144-150, ISSN 1545-9985

Hauser, M.A., Li, Y.-J., Xu, H., Noureddine, M.A., Shao, Y.S., Gullans, S.R., Scherzer, C.R., Jensen, R.V., McLaurin, A.C., Gibson, J.R., Scott, B.L., Jewett, R.M., Stenger, J.E., Schmechel, D.E., Hulette, C.M. \& Vance, J.M. (2005). Expression Profiling of Substantia Nigra in Parkinson Disease, Progressive Supranuclear Palsy, and Frontotemporal Dementia With Parkinsonism. Arch Neurol, Vol.62, (June 2005), pp. 917-921, ISSN 1538-3687

Hébert, S.S. \& De Strooper, B. (2007). miRNAs in Neurodegeneration. Science, Vol.317, (August 2007), pp. 1179-1180, ISSN 1095-9203

Hohfeld, J., Minami, Y. \& Hartl, F.-U. (1995). Hip, a Novel Cochaperone Involved in the Eukaryotic Hsc70/Hsp40 Reaction Cycle. Cell, Vol.83, (November 1995), pp. 589598, ISSN 0092-8674

Horan, M.P. (2009). Application of serial analysis of gene expression to the study of human genetic disease. Hum Genet, Vol.126, (July 2009), pp. 605-614, ISSN 1432-1203

Hughes, A.J., Daniel, S.E., Ben-Shlomo, Y. \& Lees, A.J. (2002). The accuracy of diagnosis of parkinsonian syndromes in a specialist movement disorder service. Brain, Vol.125, No.4, (April 2002), pp. 861-870, ISSN 1460-2156

Jackson, R.J. \& Standart, N. (2007). How Do MicroRNAs Regulate Gene Expression? Sci. STKE 2007, (January 2007), pp. re1, ISSN 1525-8882

John, B., Enright, A.J., Aravin, A., Tuschl, T., Sander, C. \& Marks, D.S. (2004). Human MicroRNA Targets. PLoS Biology, Vol.2, No.11, (November 2004), pp. e363, ISSN 1545-7885

Junn, E., Lee, K.-W., Jeong, B.S., Chan, T.W., Im, J.-Y. \& Mouradian, M.M. (2009). Repression of -synuclein expression and toxicity by microRNA-7. Proc Natl Acad Sci U S A, Vol.106 No.31 (August 2009), pp. 13052-13057 ISSN 1091-6490

Kim, J., Inoue, K., Ishii, J., Vanti, W.B., Voronov, S.V., Murchison, E., Hannon, G. \& Abeliovich, A. (2007). A microRNA feedback circuit in midbrain dopamine neurons. Science, Vol.317, No.5842, (August 2007), pp. 1220-1224, ISSN 1095-9203

Kim, S., eon, B.S.J., Heo, C., Im, P.S., Ahn, T.-B., Seo, J.-H., Kim, H.-S., Park, C.H., Choi, S.H., Cho, S.-H., Lee, W.J. \& Suh, Y.-H. (2004). a-Synuclein induces apoptosis by altered expression in human peripheral lymphocytes in Parkinson's disease. FASEB J, (August 2004), pp. ISSN 1530-6860

Krek, A., Grün, D., Poy, M.N., Wolf, R., Rosenberg, L., Epstein, E.J., MacMenamin, P., da Piedade, I., Gunsalus, K.C., Stoffel, M. \& Rajewsky, N. (2005). Combinatorial microRNA target predictions. Nature Genetics, Vol.37, (April 2005), pp. 495 - 500, ISSN 1546-1718

Krichevsky, A.M. \& Kosik, K.S. (2001). Neuronal RNA granules: a link between RNA localization and stimulation-dependent translation. Neuron, Vol.32, No.4, (November 2001), pp. 683-696, ISSN 1097-4199

Krichevsky, A.M., King, K.S., Donahue, C.P., Khrapko, K. \& Kosik, K.S. (2003). A microRNA array reveals extensive regulation of microRNAs during brain development. RNA, Vol.9, No.10, (October 2003), pp. 1274-1281, ISSN 1469-9001 
Lau, P. \& de Strooper, B. (2010). Dysregulated microRNAs in neurodegenerative disorders. Seminars in Cell E Developmental Biology, Vol.21 (September 2010), pp. 768-773, ISSN 1096-3634

Lewis, B.P., Burge, C.B. \& Bartel, D.P. (2005). Conserved Seed Pairing, Often Flanked by Adenosines, Indicates that Thousands of Human Genes are MicroRNA Targets. Cell, Vol.120, No.1, (January 2005), pp. 15-20, ISSN 0092-8674

Mandel, S., Grunblatt, E., Riederer, P., Amariglio, N., Jacob-Hirsch, J., Rechavi, G. \& Youdim, M.B. (2005). Gene expression profiling of sporadic Parkinson's disease substantia nigra pars compacta reveals impairment of ubiquitin-proteasome subunits, SKP1A, aldehyde dehydrogenase, and chaperone HSC-70. Ann N Y Acad Sci, Vol.1053, (August 2005), pp. 356-375, ISSN 1749-6632

Mandel, S.A., Fishman-Jacob, T. \& Youdim, M.B. (2009). Modeling sporadic Parkinson's disease by silencing the ubiquitin E3 ligase component, SKP1A. Parkinsonism Relat Disord, Vol.15, No.Suppl 3, (December 2009), pp. S148-151, ISSN 1873-5126

Maraganore, D.M., de Andrade, M., Lesnick, T.G., Strain, K.J., Farrer, M.J., Rocca, W.A., Pant, P.V.K., Frazer, K.A., Cox, D.R. \& Ballinger, D.G. (2005). High-Resolution Whole-Genome Association Study of Parkinson Disease. Am J Hum Genet, Vol.77, (September 2005), pp. 685-693, ISSN 1537-6605

Matigian, N.A., McCurdy, R.D., Féron, F., Perry, C., Smith, H., Filippich, C., McLean, D., McGrath, J., Mackay-Sim, A., Mowry, B. \& Hayward, N.K. (2008). Fibroblast and lymphoblast gene expression profiles in schizophrenia: are non-neural cells informative? PLoS ONE, Vol.3, No.6, (June 2008), pp. e2412, ISSN 1932-6203

Meister, G., Landthaler, M., Dorsett, Y. \& Tuschl, T. (2004). Sequence-specific inhibition of microRNA- and siRNA-induced RNA silencing. RNA, Vol.10, No.3, (March 2004), pp. 544-550, ISSN 1469-9001

Miller, R.M., Kiser, G.L., Kaysser-Kranich, T.M., Lockner, R.J., Palaniappan, C. \& Federoff, H.J. (2006). Robust dysregulation of gene expression in substantia nigra and striatum in Parkinson's disease. Neurobiol Dis, Vol.21, No.2, (February 2006), pp. 305-313, ISSN 0969-9961

Miska, E.A., Alvarez-Saavedra, E., Townsend, M., Yoshii, A., Sestan, N., Rakic, P., Constantine-Paton, M. \& Horvitz, H.R. (2004). Microarray analysis of microRNA expression in the developing mammalian brain. Genome Biol, Vol.5, (August 2004), pp. R68, ISSN 1465-6914

Moran, L.B., Duke, D.C., Deprez, M., Dexter, D.T., Pearce, R.K.B. \& Graeber, M.B. (2006). Whole genome expression profiling of the medial and lateral substantia nigra in Parkinson's disease. Neurogenetics, Vol.7, (March 2006), pp. 1-11, ISSN 1364-6753

Moran, L.B., Croisier, E., Duke, D.C., Kalaitzakis, M.E., Roncaroli, F., Deprez, M., Dexter, D.T., Pearce, R.K. \& Graeber, M.B. (2007). Analysis of alpha-synuclein, dopamine and parkin pathways in neuropathologically confirmed parkinsonian nigra. Acta Neuropathologica, Vol.113, No.3, (March 2007), pp. 253-263, ISSN 1432-0533

Nagatsu, T., Mogi, M., Ichinose, H. \& Togari, A. (2000). Changes in cytokines and neurotrophins in Parkinson's disease. J Neural Transm Suppl, Vol.2000, No.60, (2000), pp. 277-290, ISSN 0303-6995

Nelson, P.T. \& Keller, J.N. (2007). RNA in brain disease: no longer just "the messenger in the middle". J Neuropathol Exp Neurol, Vol.66, No.6, (June 2007), pp. 461-468, ISSN 00223069

Nelson, P.T., Wang, W.-X. \& Rajeev, B.W. (2008). MicroRNAs (miRNAs) in Neurodegenerative Diseases. Brain Pathology, Vol.18, (January 2008), pp. 130-138, ISSN 1750-3639 
Noureddine, M.A., Li, Y.J., van der Walt, J.M., Walters, R., Jewett, R.M., Xu, H., Wang, T., Walter, J.W., Scott, B.L., Hulette, C., Schmechel, D., Stenger, J.E., Dietrich, F., Vance, J.M. \& Hauser, M.A. (2005). Genomic convergence to identify candidate genes for Parkinson disease: SAGE analysis of the substantia nigra. Mov Disord, Vol.20, No.10, (October 2005), pp. 1299-1309, ISSN 1531-8257

Ohnuki, T., Nakamura, A., Okuyama, S. \& Nakamura, S. (2010). Gene expression profiling in progressively MPTP-lesioned macaques reveals molecular pathways associated with sporadic Parkinson's disease. Brain Research, Vol.1346, (June 2010), pp. 26-42, ISSN 1872-6240

Pattarini, R., Rong, Y., Qu, C. \& Morgan, J.I. (2008). Distinct mechanisms of 1-methyl-4phenyl-1,2,3,6-tetrahydropyrimidine resistance revealed by transcriptome mapping in mouse striatum. Neuroscience, Vol.155, No.4, (September 2008), pp. 1174-1194, ISSN 1873-7544

Pillai, R.S., Bhattacharyya, S.N. \& Filipowicz, W. (2007). Repression of protein synthesis by miRNAs: how many mechanisms? TRENDS in Cell Biology, Vol.17, No.3, (March 2007), pp. 118-126, ISSN 1879-3088

Plasterk, W.P.K.a.R.H.A. (2006). The Diverse Functions of MicroRNAs in Animal Development and Disease. Dev Cell, Vol.11, No.4, (October 2006), pp. 441-450, ISSN 1878-1551

Rajewsky, N. (2006). MicroRNA target predictions in animals. Nature Genetics, Vol.38, (May 2006), pp. S8 - S13, ISSN 1546-1718

Reale, M., Iarlori, C., Thomas, A., Gambi, D., Perfetti, B., Di Nicola, M. \& Onofrj, M. (2009). Peripheral cytokines profile in Parkinson's disease. Brain Behav Immun, Vol.23, No.1, (July 2008), pp. 55-63, ISSN 1090-2139

Roshan, R., Ghosh, T., Scaria, V. \& Pillai, B. (2009). MicroRNAs: novel therapeutic targets in neurodegenerative diseases. Drug Discovery Today, Vol.14, No.23/24, (December 2009), pp. 1123-1129, ISSN 1878-5832

Ryoo, H.L., Pierrotti, D. \& Joyce, J.N. (1998). Dopamine D3 receptor is decreased and D2 receptor is elevated in the striatum of Parkinson's disease. Mov Disord, Vol.13, (September 1998), pp. 788-797, ISSN 0885-3185

Santosh, S., Arora, N., Sarma, P., Pal-Bhadra, M. \& Bhadra, U. (2009). InteractionMap and Selection of microRNA Targets in Parkinson's Disease-Related Genes. Journal of Biomedicine and Biotechnology, (November 2009), pp. ID363145, ISSN 1110-7251

Saugstad, J.A. (2010). MicroRNAs as effectors of brain function with roles in ischemia and injury, neuroprotection, and neurodegeneration. J Cereb Blood Flow Metab, Vol.30, No.9, (September 2010), pp. 1564-1576, ISSN 1559-7016

Schaefer, A., O'Carroll, D., Tan, C.L., Hillman, D., Sugimori, M., Llinas, R. \& Greengard, P. (2007). Cerebellar neurodegeneration in the absence of microRNAs. JEM Vol.204, No.7, (July 2007), pp. 1553-1558, ISSN 1540-9538

Scherzer, C.R., Eklund, A.C., Morse, L.J., Liao, Z., Locascio, J.J., Fefer, D., Schwarzschild, M.A., Schlossmacher, M.G., Hauser, M.A., Vance, J.M., Sudarsky, L.R., Standaert, D.G., Growdon, J.H., Jensen, R.V. \& Gullans, S.R. (2007). Molecular markers of early Parkinson's disease based on gene expression in blood. Proc Natl Acad Sci U S A, Vol.104 No.3, (January 2007), pp. 955-960, ISSN 1091-6490

Schratt, G.M., Tuebing, F., Nigh, E.A., Kane, C.G., Sabatini, M.E., Kiebler, M. \& Greenberg, M.E. (2006). A brain-specific microRNA regulates dendritic spine development. Nature, Vol.439, No.7074, (January 2006), pp. 283-289, ISSN 1476-4687

Scott, W.K., Nance, M.A., Watts, R.L., Hubble, J.P., Koller, W.C., Lyons, K., Pahwa, R., Stern, M.B., Colcher, A., Hiner, B.C., Jankovic, J., Ondo, W.G., Allen, F.H.J., Goetz, C.G., 
Small, G.W., Masterman, D., Mastaglia, F., Laing, N.G., Stajich, J.M., Slotterbeck, B., Booze, M.W., Ribble, R.C., Rampersaud, E., West, S.G., Gibson, R.A., Middleton, L.T., Roses, A.D., Haines, J.L., Scott, B.L., Vance, J.M. \& Pericak-Vance, M.A. (2001). Complete genomic screen in Parkinson disease: evidence for multiple genes. JAMA, Vol.286, No.18, (November 2001), pp. 2239-2244, ISSN 1538-3598

Sethupathy, P. \& Collins, F.S. (2008). MicroRNA target site polymorphisms and human disease. Trends in Genetics, Vol.24 No.10, (September 2008), pp. 489-497, ISSN 01689479

Shadrina, M.I., Filatova, E.V., Karabanov, A.V., Slominsky, P.A., Illarioshkin, S.N., IvanovaSmolenskaya, I.A. \& Limborska, S.A. (2010). Expression analysis of suppression of tumorigenicity 13 gene in patients with Parkinson's disease. Neuroscience Letters, Vol.473 (April 2010), pp. 257-259, ISSN 0304-3940

Shi, Z.-z., Zhang, J.-w. \& Zheng, S. (2007). What we know about ST13, a co-factor of heat shock protein, or a tumor suppressor? Journal of Zhejiang University SCIENCE B, Vol.8, No.3, (March 2007), pp. 170-176, ISSN 1862-1783

Simunovic, F., Yi, M., Wang, Y., Stephens, R. \& Sonntag, K.C. (2010). Evidence for GenderSpecific Transcriptional Profiles of Nigral Dopamine Neurons in Parkinson Disease. PLoS ONE, Vol.5, No.1, (January 2010), pp. e8856, ISSN 1932-6203

Simunovic, F., Yi, M., Wang, Y., Macey, L., Brown, L.T., Krichevsky, A.M., Andersen, S.L., Stephens, R.M., Benes, F.M. \& Sonntag, K.C. (2009). Gene expression profiling of substantia nigra dopamine neurons: further insights into Parkinson's disease pathology. Brain, Vol.132, No.Pt 7, (December 2008), pp. 1795-1809, ISSN 1460-2156

Smirnova, L., Gräfe, A., Seiler, A., Schumacher, S., Nitsch, R. \& Wulczyn, F.G. (2005). Regulation of miRNA expression during neural cell specification. Eur J Neurosci, Vol.21, No.6, (March 2005), pp. 1469-1477, ISSN 1460-9568

Smith, D.J. (2009). Mitochondrial dysfunction in mouse models of Parkinson's disease revealed by transcriptomics and proteomics. J Bioenerg Biomembr, Vol.41, No.6, (December 2009), pp. 487-491, ISSN

Standart, N. \& Jackson, R.J. (2007). MicroRNAs repress translation of m7Gppp-capped target mRNAs in vitro by inhibiting initiation and promoting deadenylation. Genes Dev, Vol.21, (August 2007), pp. 1975-1982, ISSN 0890-9369/07

Sutherland, G.T., Halliday, G.M., Silburn, P.A., Mastaglia, F.L., Rowe, D.B., Boyle, R.S., O'Sullivan, J.D., Ly, T., Wilton, S.D. \& Mellick, G.D. (2009). Do Polymorphisms in the Familial Parkinsonism Genes Contribute to Risk for Sporadic Parkinson's Disease? Movement Disorders, Vol.24, No.6, (February 2009), pp. 833-838, ISSN 15318257

Tan, E.K., Cheah, S.Y., Fook-Chong, S., Yew, K., Chandran, V.R., Lum, S.Y. \& Yi, Z. (2005). Functional COMT variant predicts response to high dose pyridoxine in Parkinson's disease. Am J Med Genet B Neuropsychiatr Genet, Vol.137B, No.1, (August 2005), pp. 1-4, ISSN 1552-485X

van der Walt, J.M., Noureddine, M.A., Kittappa, R., Hauser, M.A., Scott, W.K., McKay, R., Zhang, F., Stajich, J.M., Fujiwara, K., Scott, B.L., Pericak-Vance, M.A., Vance, J.M. \& Martin, E.R. (2004). Fibroblast Growth Factor 20 Polymorphisms and Haplotypes Strongly Influence Risk of Parkinson Disease. The American Journal of Human Genetics, Vol.74, No.6, (June 2004), pp. 1121-1127, ISSN 1537-6605

Vasudevan, S., Tong, Y. \& Steitz, J.A. (2007). Switching from Repression to Activation: MicroRNAs Can Up-Regulate Translation. Science, Vol.318, (December 2007), pp. 1931-1934, ISSN 1095-9203 
Vo, N., Klein, M.E., Varlamova, O., Keller, D.M., Yamamoto, T., Goodman, R.H. \& Impey, S. (2005). A cAMP-response element binding protein-induced microRNA regulates neuronal morphogenesis. Proc Natl Acad Sci U S A, Vol.102, No.45, (November 2005), pp. 16426-16431, ISSN 1091-6490

Vogt, I.R., Lees, A.J., Evert, B.O., Klockgether, T., Bonin, M. \& Wüllner, U. (2006). Transcriptional changes in multiple system atrophy and Parkinson's disease putamen. Exp Neurol, Vol.199, No.2, (June 2006), pp. 465-478, ISSN 1090-2430

Wang, G., van der Walt, J.M., Mayhew, G., Li, Y.-J., Zu“"chner, S., Scott, W.K., Martin, E.R. \& Vance, J.M. (2008). Variation in the miRNA-433 Binding Site of FGF20 Confers Risk for Parkinson Disease by Overexpression of a-Synuclein. The American Journal of Human Genetics, Vol.82, (February 2008), pp. 283-289, ISSN 1537-6605

Weinberg, M.S. \& Wood, M.J.A. (2009). Short non-coding RNA biology and neurodegenerative disorders: novel disease targets and therapeutics. Human Molecular Genetics, Vol.18, No.R1, (April 2009), pp. R27-R39, ISSN 1460-2083

Whitton, P.S. (2007). Inflammation as a causative factor in the aetiology of Parkinson's disease. Br J Pharmacol, Vol.150, No.8, (April 2007), pp. 963-976, ISSN 1476-5381

Xun, Z., Sowell, R.A., Kaufman, T.C. \& Clemmer, D.E. (2007). Protein Expression in a Drosophila Model of Parkinson's Disease. J Proteome Res, Vol.6, No.1, (January 2007), pp. 348-357, ISSN 1535-3907

Yacoubian, T.A., Cantuti-Castelvetri, I., Bouzou, B., Asteris, G., McLean, P.J., Hyman, B.T. \& Standaert, D.G. (2008). Transcriptional dysregulation in a transgenic model of Parkinson disease. Neurobiology of Disease, Vol.29, (November 2007), pp. 515-528, ISSN 1095-953X

Zechner, C., Lai, L., Zechner, J.F., Geng, T., Yan, Z., Rumsey, J.W., Collia, D., Chen, Z., Wozniak, D.F., Leone, T.C. \& Kelly, D.P. (2010). Total Skeletal Muscle PGC-1 Deficiency Uncouples Mitochondrial Derangements from Fiber Type Determination and Insulin Sensitivity. Cell Metabolism, Vol.12, No.6, (December 2010), pp. 633-642, ISSN 1932-7420

Zhang, Y., James, M., Middleton, F.A. \& Davis, R.L. (2005). Transcriptional Analysis of Multiple Brain Regions in Parkinson's Disease Supports the Involvement of Specific Protein Processing, Energy Metabolism, and Signaling Pathways, and Suggests Novel Disease Mechanisms. American Journal of Medical Genetics Part B (Neuropsychiatric Genetics), Vol.137B, (August 2005), pp. 5-16, ISSN 1552-485X

Zheng, B., Liao, Z., Locascio, J.J., Lesniak, K.A., Roderick, S.S., Watt, M.L., Eklund, A.C., Zhang-James, Y., Kim, P.D., Hauser, M.A., Grünblatt, E., Moran, L.B., Mandel, S.A., Riederer, P., Miller, R.M., Federoff, H.J., Wüllner, U., Papapetropoulos, S., Youdim, M.B., Cantuti-Castelvetri, I., Young, A.B., Vance, J.M., Davis, R.L., Hedreen, J.C., Adler, C.H., Beach, T.G., Graeber, M.B., Middleton, F.A., Rochet, J.-C. \& Scherzer, C.R. (2010). PGC-1a, A Potential Therapeutic Target for Early Intervention in Parkinson's Disease. Sci Transl Med, Vol.2, No.52, (October 2010), pp. 52ra73, ISSN 1946-6242 


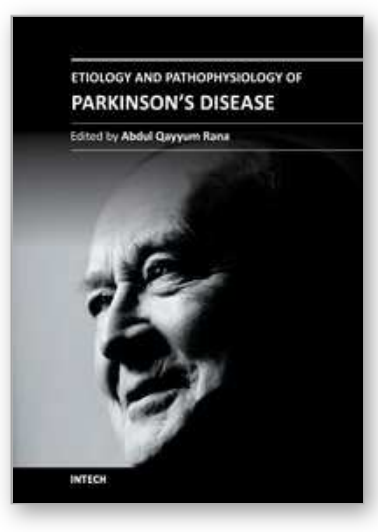

\author{
Etiology and Pathophysiology of Parkinson's Disease \\ Edited by Prof. Abdul Qayyum Rana
}

ISBN 978-953-307-462-7

Hard cover, 542 pages

Publisher InTech

Published online 12, October, 2011

Published in print edition October, 2011

This book about Parkinsonâ $€^{\mathrm{TM}} \mathrm{S}$ disease provides a detailed account of etiology and pathophysiology of Parkinsonâ€ ${ }^{\mathrm{TM}} \mathrm{s}$ disease, a complicated neurological condition. Environmental and genetic factors involved in the causation of Parkinsonâ€ ${ }^{\mathrm{TM}} \mathrm{S}$ disease have been discussed in detail. This book can be used by basic scientists as well as researchers. Neuroscience fellows and life science readers can also obtain sufficient information. Beside genetic factors, other pathophysiological aspects of Parkinsonâ $€^{\mathrm{TM}} \mathrm{s}$ disease have been discussed in detail. Up to date information about the changes in various neurotransmitters, inflammatory responses, oxidative pathways and biomarkers has been described at length. Each section has been written by one or more faculty members of well known academic institutions. Thus, this book brings forth both clinical and basic science aspects of Parkinsonâ€ ${ }^{\mathrm{TM}} \mathrm{S}$ disease.

\title{
How to reference
}

In order to correctly reference this scholarly work, feel free to copy and paste the following:

Elena Filatova, Maria Shadrina, Petr Slominsky and Svetlana Limborska (2011). Analysis of Transcriptome Alterations in Parkinson's Disease, Etiology and Pathophysiology of Parkinson's Disease, Prof. Abdul Qayyum Rana (Ed.), ISBN: 978-953-307-462-7, InTech, Available from: http://www.intechopen.com/books/etiology-andpathophysiology-of-parkinson-s-disease/analysis-of-transcriptome-alterations-in-parkinson-s-disease

\section{INTECH}

open science | open minds

\author{
InTech Europe \\ University Campus STeP Ri \\ Slavka Krautzeka 83/A \\ 51000 Rijeka, Croatia \\ Phone: +385 (51) 770447 \\ Fax: +385 (51) 686166 \\ www.intechopen.com
}

\author{
InTech China \\ Unit 405, Office Block, Hotel Equatorial Shanghai \\ No.65, Yan An Road (West), Shanghai, 200040, China \\ 中国上海市延安西路65号上海国际贵都大饭店办公楼405单元 \\ Phone: +86-21-62489820 \\ Fax: +86-21-62489821
}


(C) 2011 The Author(s). Licensee IntechOpen. This is an open access article distributed under the terms of the Creative Commons Attribution 3.0 License, which permits unrestricted use, distribution, and reproduction in any medium, provided the original work is properly cited. 